3. Вишневський О. Українська освіта на шляху реформ. Актуальні питання сучасної української освіти і змісту виховання Статті. Нариси. Концепції / О. Вишневський. - Дрогобич, 2009. - 72 c.

4. Падалка Г. М. Учитель, музика, діти / Г.М. Падалка - К.: Муз. Україна. 1982. - 144 с.

5. Сотська Г. І. Образотворче мистецтво як засіб розвитку особистості / Г. І. Сотська // Мистецтво у розвитку особистості : монографія / за ред. Н. Г. Ничкало. - Чернівці : Зелена Буковина, 2006 - C. $137-146$

6. Чайка В. М. Підготовка майбутнього вчителя до саморегуляції педагогічної діяльності: монографія / за ред. Г.В. Терещука / В. М. Чайка. - Тернопіль: ТНПУ, 2006. - 275 с.

7. Якса Н. В. Основи педагогічних знань / Н.В. Якса. - Навчальний посібник. - Київ.: Знання, $2007-358 \mathrm{c}$

\title{
References
}

1. Boryn H. V. Khudozhno-estetychnyi rozvytok ditei: napriamy udoskonalennia pidhotovky maibutnikh pedahohiv do vzaiemodii z simiamy vykhovantsiv / H. V. Boryn // Osvitnii prostir Ukrainy. - 2018. - №12. - S. 56-61.

2. Honcharenko S.U. Pedahohichni doslidzhennia : metodolohichni porady molodym naukovtsiam. / S.U. Honcharenko. - Kyiv - Vinnytsia: DOV "Vinnytsia", 2008. - 278 s.

3. Vyshnevskyi O. Ukrainska osvita na shliakhu reform. Aktualni pytannia suchasnoi ukrainskoi osvity i zmistu vykhovannia Statti. Narysy. Kontseptsii. - Drohobych, 2009. - 72 s.

4. Padalka H.M. Uchytel, muzyka, dity / H.M. Padalka - K.: Muz. Ukraina. 1982. - 144 s.

5. Sotska H.I. Obrazotvorche mystetstvo yak zasib rozvytku osobystosti / H.I. Sotska // Mystetstvo u rozvytku osobystosti : monohrafiia / za red. N.H. Nychkalo. - Chernivtsi : Zelena Bukovyna, 2006. S. $137-146$

6. Chaika V.M. Pidhotovka maibutnoho vchytelia do samorehuliatsii pedahohichnoi diialnosti: monohrafiia / za red. H.V. Tereshchuka /V.M. Chaika. - Ternopil: TNPU, 2006. - $275 \mathrm{~s}$.

7. Iaksa N.V. Osnovy pedahohichnykh znan / N.V. Yaksa. - Navchalnyi posibnyk. - Kyiv.: Znannia, $2007-358 \mathrm{~s}$.

\section{Вікторія Завидович,}

Національна академія Державної Прикордонної служби України імені Б. Хмельницького (м. Хмельницький, Україна)

Victoriia Zavydovych, National Academy of the State Border Guard Service of Ukraine named after Bohdan Khmelnytskyi (Khmelnytskyi, Ukraine) zvv2012@ukr.net

\section{КРИТЕРІЇ, ПОКАЗНИКИ ТА РІВНІ РОЗВИТКУ КОМУНІКАТИВНОЇ КОМПЕТЕНТНОСТІ ОФЩЕРІВ-ПРИКОРДОННИКІВ В УМОВАХ МАГІСТРАТУРИ}

\section{CRITERIA, INDICATORS AND LEVELS OF DEVELOPMENT OF COMMUNICATIVE COMPETENCE OF BORDER GUARDS IN THE MASTER'S CONDITIONS}

Проблема розвитку комунікативної компетентності як основи взаєморозуміння $i$ взаємодії сьогодні набуває все більиой актуальності. Особливі вимоги до володіння означено юкомпетентністю висуваються до офіџерів-прикордонииків. У статті висвітлено та обтрунтовано наукові підходи у з'ясуванні критеріїв, показників і рівнів розвитку досліджуваного феномена. Визначено такі критерій: мотиваційний, когнітивний, діяльнісний, які безпосередньо співвідносяться зі структурними компонентами. Для вказаних критеріїв установлені відповідні показники, ицо їх характеризують, рівні розвитку 
(високий, достатній, задовільний), а також методи та засоби діагностики, щцо надасть змогу визначити сучасний стан та передбачити динаміку розвитку комунікативної компетентності. Проаналізовано розвиток комунікативної компетентності офіцерівприкордонників в умовах сучасної магістерської освіти.

Ключові слова: комунікативна компетентність; критерії, показники та рівні розвитку; офічер-прикордонник; магістратура.

On the basis of analysis of criteria and indicators of communicative competence of specialists of different profile and on the basis of these researches and features of activity of border guard officer the criteria of the latter are distinguished: motivational, cognitive, activity. The indicators of each of these criteria are described. Indicators of motivational criterion are: communicative; organizational skills and ability to handle conflict situations, emotional comfort in communication. Indicators of cognitive criteria are defined: knowledge of border guards officers about the main types of professional communication, features of professional etiquette, nature and stages of conversation with subordinates; understanding of the rules of business negotiations; knowledge of norms of non-verbal and verbal behavior. Indicators of activity criterion are defined ability: to build logically correct and reasoned statements, to conduct dialogue; correctly using the strategy and tactics of conversation; overcome communication barriers; listen and defend your position, as well as the skills of a verbal and non-verbal communication culture. Three levels of development of this personal phenomenon are characterized - high, sufficient, satisfactory, methods and means of diagnostics. The analyzed indicators, criteria and levels will help to determine the current state and predict dynamics of development of communicative competence.

The development of competence in the conditions of modern master's education is analyzed. A master's degree is a deepening, systematization, updating of professional knowledge, development of practical skills in connection with the increase of requirements to the level of qualification and the need to master new ways of solving professional problems.

The effectiveness of the professional work of a border guard depends on many components. Among them is a special competence in communication, which is the core of the professionalism of the future master - graduate master and provides the ability to solve the language problem of communication in specific, typical for professional language situations. Communication objectives are defined by the goals of the joint activity. The content of communicative competence is determined by the purpose of its development and the requirements of professional training of future military leaders.

Thus, an important place in the process of professional psychological and pedagogical preparation of the future career is the development of communicative competence, which is the core of professional and interpersonal and other competencies. The modern leader should have a high level of communication skills, as well as perceptual and organizational skills, flexibility and tolerance in communication, be empathetic and reflective.

Key words: communicative competence, criteria, indicators and levels of development, future manager, off-border guard, master's degree.

Постановка проблеми. Ефективність професійної діяльності офіцера-прикордонника залежить від багатьох складників. Серед них особливе місце належить комунікативній компетентності, яка становить ядро професіоналізму майбутнього керівника-офіцера - випускника магістратури і передбачає вміння вирішувати завдання комунікування, визначені цілями спільної діяльності в конкретних, типових для професійної діяльності ситуаціях. Зміст комунікативної компетентності визначається метою іiі розвитку та вимогами фахової підготовки офіцерів-прикордонників. Розвиток досліджуваного явища - процес поетапний, він містить організацію комунікування, розвиток комунікативних здібностей і умінь. Маркерами розвитку комунікативної компетентності при цьому можуть виступати: ступінь 
відповідності ситуації використовуваних офіцером мовних засобів, чіткість і логічність викладу своїх думок, різноманітність використовуваних комунікативних прийомів, відповідність стилю спілкування і займаної рольової позиції; відсутність конфліктно-деструктивних елементів підчасспілкування [1]. Передбачуваний результат - комунікативна компетентність визначеного рівня.

Для з'ясування результативності роботи щодо розвитку комунікативної компетентності важливе значення має обгрунтування критеріїв, показників та рівнів розвитку досліджуваного феномена. Критерії та їх показники допомагають порівняти передбачені результати з реальними явищами, з'ясувати, як можна досягти результату педагогічної дії, тобто безперервно підвищувати рівень комунікативної компетентності офіцерів-прикордонників, i зокрема у процесі їх магістерської підготовки. Магістерську освіту ми розглядаємо як багатоаспектне поняття, що має своїм завданням удосконалювати професійну діяльність, без чого фахівець не може розвиватися й самореалізовуватися.

Аналіз останніх досліджень і публікацій. У наукових дослідженнях різних галузей триває теоретичний аналіз і осмислення даної категорії, розширюється їі змістовне наповнення. Питанням вивчення процесу формування й розвитку комунікативної компетентності фахівця присвячено дослідження А. Вербицького, І. Зимньої, М. Лук'янової, В.Конецької, Н. Кузьминої(описано характеристики комунікативної компетентності, розроблено структуру, механізми і фактори розвитку). Та попри накопичений достатній теоретичний та емпіричний матеріал як у вітчизняних,так і зарубіжних наукових доробках з педагогіки (О. Діденко, О. Берестенко, Н. Берестецька, С. Годлевська, О. Мисечко, Г. М'ясоїд, Ю. Смельянов, В. Кан-Калік, В. Куніцина, Л. Петровська та ін.), психології (М. Беннет, Л. ВиготськийО. Волобуєва та ін.) та інших наук (М. Бергельсон, Є. Верещагін, В. Костомаров, О. Леонтович та ін.), критерії, показники та рівніiї розвитку в офіцерівприкордонників під час навчання у магістратурі не були об'єктом грунтовного аналізу.

3 огляду на це метою статті є визначення й обгрунтування критеріїв, показників та рівнів розвитку комунікативної компетентності офіцерів-прикордонників у процесі магістерської підготовки.

Виклад основного матеріалу. Розробка механізму визначення стану розвитку комунікативної компетентності передусім потребує з'ясування базових понять, до яких належать “критерій”, “показник”, “рівень”. Згідно з визначенням, яке надає Філософський словник, критерій - це засіб перевірки того чи іншого твердження, гіпотези, теоретичної побудови [2, с. 221]; у Великому тлумачному словнику сучасної української мови знаходимо таку дефініцію: критерій - провідна ознака, на основі якої здійснюється оцінка, визначення або класифікація чого-небудь; мірило оцінки; те, що засвідчує об'єктивну істинність пізнання [3, с. 588].

У психолого-педагогічній літературі найбільш поширеними є такі визначення цього поняття: 1) критерій - набір якісних характеристик, що використовуються для винесення судження щодо продукту виконання або як інструмент оцінювання [4, c. 217]; 2) найзагальніша сутнісна ознака, на основі якої здійснюють оцінку, порівняння реальних педагогічних явищ, при цьому рівень виявлення, якісна сформованість, визначеність критерію виражається в показниках [5, с. 93]. До виділення й обгрунтування критеріїв вчені висувають певні вимоги: критерії мають містити основні закономірності функціонування об'єкта; відображати необхідні стійкі й постійні ознаки та якості;за допомогою критеріїв повинні встановлюватися 
зв'язки між усіма компонентами аналізованого явища; критерії повинні розкриватися через низку показників; мають відбивати динаміку вимірюваної якості в часі та просторі; якісні показники повинні виступати в єдності з кількісними показниками та доповнювати один одного[6;7]. Також критерії мають відбивати такі властивості:володіння вербальними й невербальними комунікативними кодами, вміння діагностувати особистісні якості та якості комуніканта, виробляти стратегію, тактику і техніку взаємодії 3 оточенням; організовувати спільну діяльність для досягнення певних професійно значущих цілей тощо.

Наукове товариство підкреслює, що правильний вибір критерію $є$ однією 3 найважливіших вимог до експерименту, оскільки це допомагає визначити розвиток тієї властивості, на вивчення якої спрямоване дослідження. Науковиця Г. М'ясоїд для визначення стану комунікативної культури соціальних інспекторів використовує інформаційно-пізнавальний (професійно-етичні якості, знання про етичні норми ділового спілкування), мотиваційно-ціннісний (інтеріоризація цінностей соціальної роботи, сформованість професійних і особистісних мотивацій) та операційнодіяльнісний критерії (комунікативні, інтерактивній перцептивні уміння) критерії [8, c. 9,10$]$.

Тож у межах дослідження розуміємо критерій як провідну сутнісну ознаку та інструмент оцінювання, на основі якого можна об'єктивно визначити рівень розвитку комунікативної компетентності офіцера-магістранта. 3 урахуванням висновків попередніх досліджень щодо уточнення сутності, змісту та структури комунікативної компетентності офіцерів-прикордонників, а також за результатами аналізу наукових підходів щодо діагностики комунікативної компетентності визначимо мотиваційний, когнітивний, діяльнісний критерії розвитку досліджуваного явища та розкриємо їх зміст. Мотиваційний критерій (усвідомлення вагомості комунікативних питань у професійній діяльності, наполегливості у збагаченні власного комунікативного досвіду, включеності комунікативних норм у особистісну сферу) - визначає якість професійної підготовки на основі цілеспрямованого розвитку основних компонентів комунікативної компетентності з метою ефективного виконання професійної діяльності, а також прагнення до отримання знань. Когнітивний (діагностика рівня розвитку комунікативних знань) - полягає у дієвості знань, навичок та вмінь у процесі професійної діяльності, відображає певний рівень комунікативної компетентності (лінгвістична база, теоретичні комунікативні знання; знання засобів впливу на аудиторію та прийомів справляти враження; засобів i прийомів установлення, підтримки та завершення мовленнєвого контакту для досягнення певної мети; володіння основами самоконтролю, самовиховання та знаннями норм комунікативної поведінки). Діяльнісний (уміння використовувати комунікативні знання у професійній діяльності) - представлений комплексом умінь і навичок моделювання педагогічних завдань, ефективного розв'язання нестандартних ситуацій; методичних вмінь; комунікативних навичок та вмінь (усне й письмове мовлення, вербальна і невербальна комунікація); знань специфіки професійної взаємодії, вміння прогнозувати та проектувати, знаходити оптимальні рішення, моделювати ситуації майбутньої управлінської діяльності.

Визначені критерії розкриваються в сукупності показників, кожен 3 яких $\epsilon$ характеристикою певного аспекту, мірою вираження критерію, тобто “свідченням, доказом, ознакою, наочними даними про результати роботи” [3, с. 1024]. Він слугує типовим і конкретним проявом однієї із суттєвих ознак певної особистісної якості,за допомогою якого можна оцінити якість та рівень сформованості/розвитку того чи 
іншого педагогічного феномена. Показник $є$ складником критерію, тому ступінь вияву, якісна сформованість, визначеність критерію виражаються саме конкретними показниками. При цьому розрізняють кількісні показники, які фіксують наявність чи відсутність якої-небудь властивості, та якісні показники, які фіксують міру вираженості чи розвитку властивості [9, с. 218]. Отже, показники - це якісні або кількісні характеристики сформованості кожної окремої якості, тобто ступінь сформованості/розвитку того чи іншого критерію. Зокрема В. Кан-Калік [10] вважає, що про сформованість комунікативної компетентності свідчать такі показники: комунікативний контроль, уміння слухати, способи реагування в конфлікті, ступінь агресивності, рівень конфліктності, фрустраційна толерантність, самоконтроль, емпатія, готовність до співробітництва, мотиваційні установки, зокрема орієнтація на уникнення невдач, нетерпимість до невизначеності, підвищене прагнення до статусного росту, організаційні схильності й самооцінка та ін.

Показниками мотиваційного критерію розвитку комунікативної компетентності офіцера-магістранта є: 1) мотивація до навчання та подальшої професійної діяльності; 2) самоосвіта та самовдосконалення протягом життя, прагнення збагачення знань, бажання досягти майстерності у комунікуванні; 3) комунікативний контроль, організаторські здібності;4) бажання слухати (чути) думку реципієнта у професійній взаємодії, обираючи вірні комунікативні стратегії і тактики.

Показники когнітивного критерію: 1) прогностичність, знання особливостей вербальної та невербальної взаємодії, цілісність аналізу ситуацій; 2) розуміння сутності мови як суспільного явища, іiі системи та рівнів, зв'язку лексичної, фонетичної, граматичної підсистем, особливостей стилістики; 3) знання форм, засобів і методів ухилення від конфліктів у процесі навчання та професійної діяльності, подолання бар'єрів, що виникають; 4) обізнаність у структурі комунікативної діяльності, особливостях усного та писемного комунікування, етики професійної комунікації.

Для діяльнісного критерію властиві такі показники: 1) уміння приймати обгрунтовані рішення, інструктувати,конструктивно вирішувати проблемні ситуації, організовувати діалогічну взаємодію у процесі професійної діяльності; 2) уміння вибудовувати службові розмови, наводити аргументи, впливати на реципієнта за допомогою вербальних та невербальних кодів, оцінювати його емоційний стан, переконувати; 3) добирати та систематизувати матеріал, будувати логічно правильні й точні висловлювання, вести співбесіди, дискусіі, засідання, відеоконференції, перемовини; 4) дотримуватись умов ефективної комунікації, толерантності, емпатії у керівній діяльності.

Науковий підхід до проблеми розвитку комунікативної компетентності офіцера-прикордонника - майбутнього керівника військової справи зумовлює необхідність виявлення якісних характеристик ефективності розвитку цього особистісного феномена, тобто рівнів. Поняття “рівень" визначається як міра величини, розвитку, значущість чогось; ступінь чиєїсь освіти, культури, підготовки ступінь виявлення показника того чи іншого критерію [3, с. 1223], умовна міра, що дає можливість дати оцінку, досліджуваному явищу.

У визначенні рівнів комунікативної компетентності немає єдиної, спільної наукової думки: і кількість, і термінологія, і критерії обгрунтування рівнів суттєво різняться. Здебільшого при визначенні рівнів сформованості/розвитку педагогічних явищ науковці виокремлюють такі: високий, середній та низький $[11$, с. 8]. Оригінальним є підхід до визначення рівнів культури професійного спілкування 
дослідниці О. Берестенко, що виділяє п'ять рівнів культури професійного спілкування фахівця: низький (примітивний, маніпулятивний); елементарний (конвенційний); базовий (стандартизований); досконалий (діловий); високий (творчий, духовний ) [12, с. 163]. Три рівні (низький, середній та високий) сформованості професійної комунікативної компетентності в майбутніх соціальних працівників виокремлює i С. Годлевська $[13$, с. 12]. Вартою уваги вважаємо класифікацію рівнів сформованості професійної компетентності, побудовану на основі таксономії цілей Б. Блума, відповідно до якої категорії навчальних цілей відповідають таким рівням: знання репродуктивний рівень, розуміння - адаптивний рівень, застосування конструктивний рівень, аналіз - творчий рівень, синтез - дослідницький рівень, оцінювання - оціночно-узагальнювальний рівень [14].

Переважна більшість вчених вважає, що трирівнева система вимірювання дозволяє досить повно визначити рівень розвитку комунікативної компетентності, до того ж вона $є$ досить практичною та зручною у використанні.Проте запропоновані класифікації, на нашу думку, є неточними в характеристиці офіцерів-прикордонників саме магістерської підготовки, які мають певний навчальний i життєвий комунікативний досвід. Адже теоретична підготовка в системі бакалаврської освіти в поєднанні 3 практикою комунікативної діяльності сприяють розвитку професійної свідомості та створюють умови для переходу від стихійного (низького) до більш високого рівня розвитку комунікативної компетентності. Про низький або ж нульовий рівень розвитку комунікативної компетентності на етапі магістерської підготовки не йдеться через те, що магістерська підготовка - це вже набуті i сформовані ключові компетентності, де чітко простежуються стійкі пізнавальні інтереси у сфері комунікації, хоча їх рівень розвитку у всіх далеко не однаковий.

Тож ураховуючи напрацювання науковців, а також характеристики критеріїв та показників, що дозволяють оцінити рівень розвитку комунікативної компетентності офіцерів-прикордонників, - ми виокремили високий, достатній і задовільний рівні.

Високий рівень (A) характеризується вмотивованою орієнтацією на розвиток комунікативної компетентності, плідну творчу працю у військовій сфері. Офіцери володіють глибокими фаховими знаннями, вільно висловлюють власні оригінальні та креативні думки, ідеї, переконання. Їм притаманні ефективність вербального й невербального впливу, комунікативна досконалість (точність, правильність, доречність, зрозумілість, чистота, багатство і різноманітність, виразність); завжди вдається вести діалог, долати комунікативні бар'єри, розробляти стратегію комунікативної поведінки для ухвалення управлінських рішень; вони грунтовно знаються на професійних нормах й способах взаємодії, різноманітних комунікативних тактиках, правилах та обмеженнях в комунікуванні, особливостях поведінки в складних, кризових i конфліктних ситуаціях; зацікавлені у різних шляхах підвищення своєї професійної майстерності, прагнутьпостійного самовдосконалення і саморозвитку.

Достатній рівень (Б) визначається усвідомленням значущості розвитку комунікативної компетентності, можливістю професійного зростання, проте відсутня стійка й чітка мотивація. У таких офіцерів сформовані переважно стійкі пізнавальніінтереси в сфері професійної комунікативної діяльності; їм вдається вести діалог 3 дотриманням законіві тактик розмови; загалом вміють слухати та інтерпретувати невербальну поведінку співрозмовника;володіють стратегіями виходу 3 конфліктних ситуацій,зазвичай уміють долати комунікативні бар'сри; 
можуть вести ділові розмови й розробляти стратегію комунікативної поведінки для ухвалення управлінського рішення; спрямованість на безперервний саморозвиток переважно виражена.

Для задовільного рівня (B) характерні нестійкі інтереси до розвитку досліджуваної компетентності;здобуті фахові знання реалізуються епізодично та несистематично; цікавість до даної проблеми зазвичай присутня, але здебільшого це пов'язано із вдалим подальшим працевлаштуванням; для таких офіцерів характерна недостатня розвиненість ключових умінь, навичок професійно-комунікативної діяльності; їм деколи не вдається подолати певні комунікативні бар'єри; інколи важко вести ділові розмови й розробляти стратегію комунікативної поведінки, що впливає на ухвалення управлінського рішення; не завжди вміють слухати та інтерпретувати невербальну поведінку співрозмовника; не завжди володіють ефективними стратегіями виходу 3 конфліктних ситуацій, але, як правило, відкриті до діалогу; прагнення до самоосвіти й розвитку комунікативних навичок, необхідних для вирішення проблемних ситуацій у фаховій діяльності, виявлене епізодично.

Отже, окреслені показники, маючи свої рівні розвитку, в сукупності дають інтегральний показник комунікативної компетентності.

Щодо діагностики й оцінки рівня комунікативної компетентності психологопедагогічним інструментарієм, що найбільш повно відповідає задуму дослідження, нами було ретельно підібрано такі методики:

1. Методика оцінки рівня комунікативного контролю (М. Шнайдер).

2. Методика оцінки комунікативної соціальної компетентності (КСК).

3. Тест "Комунікативна компетентність" Л. Міхельсона (дозволяє виявити три типи позицій в спілкуванні: залежну, пасивну, компетентну, а також вираженість цих позицій у 12 різних типах ситуацій.

4. Методика діагностики комунікативної установки (В. Бойко) - для визначення двох показників установки в спілкуванні: ступеня негативності комунікативної установки та рівня комунікативної толерантності.

5. Методика вивчення комунікативних і організаторських здібностей (КОС-1) (В.Синявський, Б.Федоришин) - визначає рівень розвитку навичок до спілкування й управління іншими.

6. Тест оцінки комунікативних умінь (А. Кухарчук, В. Лях, А. Широкова) виокремлює здібності адекватно оцінювати партнера по спілкуванню, вміння встановити дружню атмосферу, зрозуміти проблеми співрозмовника тощо.

7. Тест СЖО Д.Леонтьєва й методика “Діагностика реальної структури ціннісних орієнтацій особистості” С.Бубнова - для вивчення життєвих орієнтацій i актуальних смислових станів особистості, а також ціннісно-смислового компонента комунікативної компетентності.

8. Тест "Вимірювання комунікативноїі соціальної компетентності” КОСКОМ В. Н. Куніциної - для вивчення комунікативного, соціального й особистісного компонентів (за 12-бальною системою оцінюються: комунікативна компетентність (КК), уміння самопрезентації (УС), вербальна компетентність (ВК), розуміння ситуації (РС), моральні установки (МУ), мотивація досягнення (МД), емоційна стійкість (ЕС) тощо [15].

Попри стислі рамки статті, що не дозволяють проаналізувати результатів дослідження комунікативної компетентності за відібраними із цією метою методиками, зауважимо, що за правильно підібраної методики корекція і вдосконалення навичок комунікативної сфери, розвиток комунікативних здібностей i кому- 
нікативних умінь, а також мотивація для підвищення професійно важливої компетентності неминучі.

На практиці стає ясно, що здатність офіцера-прикордонника чинити активний комунікативний вплив - командувати, переконувати, надихати - це мистецтво, якого потрібно і можна вчитися.

Висновки. Основними критеріями розвитку офіцерів-прикордонників в умовах магістратури відповідно до структури й змісту досліджуваного явища нами визначено мотиваційний, когнітивний і діяльнісний. 3'ясування показників і рівнів розвитку цієі компетентності допомагає проаналізувати характеристики, які необхідні в майбутньому офіцерам-прикордонникам при переході на наступний, вищий рівень професійного зростання - рівень керівника військової сфери. Перспективами подальших наукових розвідок вбачаємо опрацювання методичних рекомендацій науково-педагогічному складу щодо розвитку комунікативної компетентності офіцерів-прикордонників в умовах магістратури.

\section{Література}

1. Машин В. Н., Свиридов А. А. Коммуникативная культура курсантов военных вузов как междисциплинарный феномен.Вестник Тамбовского университета. Сер.: Гуманитарные науки. 2013. № 11 (127). С. 143-148.

2. Философский словарь /[под ред. И. Т. Фролова]. 5-е изд. Москва: Политиздат, 1987. 590 с.

3. Великий тлумачний словник сучасної української мови: 250000 / уклад. та гол. ред. В.Т. Бусел. Київ; Ірпінь:Перун, 2005. VIII, 1728 с.

4. Старша школа зарубіжжя: організація та зміст освіти: монографія / [Г. С. Сгоров, М. Ю. Красовицький, О. І. Локшина та ін.]; за ред. О. І. Локшиної. Київ : СПД Богданова А. M., 2006. $232 \mathrm{c}$.

5. Галімов А. В. Теоретико-методичні засади підготовки майбутніх офіцерів-прикордонників до виховної роботи з особовим складом: монографія / Галімов А. В. Хмельницький: Вид-во Національної академії Державної прикордонно служби України імені Б. Хмельницького, 2004. $376 \mathrm{c}$.

6. Борытко Н. М. Диагностическая деятельность педагога / Н. М. Борытко, В. А. Сластенин, И. А. Колесникова. Москва: Изд. центр “Академия", 2006. 288 с.

7. Коростіль Л.А. Самоосвіта особистості як соціальне та пе- дагогічне явище. Педагогічні науки : зб. наук. праць. Суми: Видавництво СумДПУ, 2009. № 1. С. 138-145.

8. М'ясоїд Г. І. Педагогічні умови розвитку комунікативної культури соціальних інспекторів у процесі підвищення кваліфікації: автореф. дис. на здобуття наук. ступеня канд. пед. наук: спец. 13.00.04 "Теорія і методика професійної освіти". Тернопільський національний педагогічний університет імені Володимира Гнатюка. Тернопіль, 2005. 20 с.

9. Андреева Г. М. Социальная психология: учебник для высших учебных заведений. Москва: Аспект Пресс, 1999. 376 с.

10. Кан-Калик В. А. Учителю о педагогическом общении: кн. для учителя. Москва: Просвещение, 1987. $190 \mathrm{c}$.

11. Сокол I. В. Формування професійної компетентності майбутніх судноводіїв у процесі вивчення фахових дисциплін: автореф. дис. на здобуття наук. ступеня канд. пед. наук: спец. 13.00.04 “Теорія і методика професійної освіти”; Херсонський державний університет. Херсон, $2011.20 \mathrm{c}$.

12. Берестенко О. Г. Культура професійного спілкування: навч.-метод. посібник. Луганськ: Вид-во ДЗ “ЛНУ ім. Т. Шевченка", 2013. 298 с.

13. Годлевська Д. М. Формування комунікативної компетентності майбутніх працівників в умовах педагогічного університету: автореф. дис. на здобуття наук. ступеня канд. пед. наук: спец. 13.00.05 "Соціальна педагогіка". Національний педагогічний університет імені М. П. Драгоманова. Київ, 2007. 22 с.

14. Bloom B. S. Taxonomy of Education Objectives / B. S. Bloom // Handbook 1 : Cognitive Domain. Harlow, 1950.

15. Куницына В.Н., Казаринова Н. В., Погольша В. М. Межличностное общение: учеб. для вузов. СПб.: Питер, 2001. 544 с. 


\section{References}

1. Mashy'n V. N., Svy'ry'dov A. A. Kommuny'katy'vnaya kul'tura kursantov voennyix vuzov kak mezhdy'scy'ply'narnyij fenomen // Vestny'k Tambovskogo uny'versy'teta. Ser.: Gumany'tarnyie nauky'. 2013. \# 11 (127). S. 143-148.

2. Fy' losofsky’j slovar'/[pod red. Y’. T. Frolova]. 5-e y’zd. Moskva: Poly'ty’zdat, 1987. 590s.

3. Vely’ky'j tlumachny'j slovny'k suchasnoyi ukrayins'koyi movy’: 250000 / uklad. Ta gol. Red. V.T. Busel. Ky'yiv; Irpin' : Perun, 2005. VIII, 1728 s.

4. Starsha shkola zarubizhzhya: organizaciya ta zmist osvity' : monografiya / [G. S. Yegorov, M. Yu. Krasovy'cz'ky`j, O. I. Lokshy`na ta in.]; za red. O. I. Lokshy`noyi. Ky' yiv : SPD Bogdanova A. M., $2006.232 \mathrm{~s}$.

5. Galimov A. V. Teorety 'ko-metody'chni zasady' pidgotovky' majbutnix oficeriv-pry 'kordonny' kiv do vy'xovnoyi roboty' z osobovy'm skladom: monografiya / Galimov A. V. Xmel'ny'cz'ky'j: Vy'd-vo Nacional 'noyi akademiyi Derzhavnoyi pry kordonno sluzhby' Ukrayiny' imeni B. Xmel'ny'cz' kogo, $2004.376 \mathrm{~s}$

6. Borytko, N. M., Slastenin, V.A. and Kolesnikova, I.A. Diagnos- tic activity of the teacher, Moscow, Russia, 2006, 288 p.

7. Korostil` L. A. Samoosvita osoby'stosti yak social 'ne ta pe- dagogichne yavy`shhe / L.A. Korostil' .// Pedagogichni nauky' : zb. nauk. pracz'. Sumy': Vy'davny'cztvo SumDPU, 2009. \# 1. S. 138-145. Korostyl, L.A. Self-Education as a social and pedagogical phe- nomenon // Pedagogical Science, Sumy, 2001, №1, P. 138-145.

8. M'yasoyid G. I. Pedagogichni umovy' rozvy'tku komunikaty'vnoyi kul'tury' social ny'x inspektoriv u procesi pidvy'shhennya kvalifikaciyi: avtoref. dy's. na zdobuttya nauk. stupenya kand. ped. nauk: specz. 13.00.04 "Teoriya i metody'ka profesijnoyi osvity" / G. I. M'yasoyid; Ternopil's'ky'j nacional ny'j pedagogichny'j universy' tet imeni Volody'my' ra Gnatyuka. - Ternopil', 2005. $20 \mathrm{~s}$.

9. Andreeva G. M. Socy'al'naya psy'xology'ya: uchebny'k dlya vyisshy'x uchebnyix zavedeny'j / G. M. Andreeva. Moskva: Aspekt Press, 1999.376 s.

10. Kan-Kaly'k V. A. Uchy'telyu o pedagogy'cheskom obshheny'y': kn. dlya uchy'telya / V. A. KanKaly'k. Moskva: Prosveshheny`e, 1987. 190 s.

11. Sokol I. V. Formuvannia profesiinoi kompetentnosti maibutnih sudnovodiiv u protsesi vyvchennia fahovyh dystsyplin: avtoref. dys. na zdobuttya nauk. stupennya kand. ped. nauk: spets. 13.00.04 "Teoriia i metodyka profesiinoi osvity" / I. V. Sokol; Khersonskii derzhavnui universitet. Kherson, $2011.20 \mathrm{~s}$.

12. Berestenko O. H. Kultura profesiinoho spilkuvannia, Luhansk [Culture of professional communication]. Vyd-vo DZ "LNU imeni Tarasa Shevchenka", 2013, 300 s.

13. Godlevska D. M. Formuvannya profesiinoi komynikatyvnoi kompetentnosti maibutnikh sotsialnyh pratsivnykiv $\mathrm{v}$ umovah pedagogichnogo universitetu: avtoref. dys. na zdobuttya nauk. stupennya kand. ped. nauk: spets. 13.00.05 "Sotsialna pedagogika" / D. M. Godlevska; Natsionalnyi pedagogichnyi universitet imeni M. P. Dragomanova. K., 2007. $22 \mathrm{~s}$.

14. Bloom B. S. Taxonomy of Education Objectives / B. S. Bloom // Handbook 1 : Cognitive Domain. Harlow, 1950.

15. Kunicyna V.N., Kazarinova N. V., Pogol'sha V. M. Mezhlichnostnoe obshhenie: ucheb. dlya vuzov. SPb.: Piter, 2001. $544 \mathrm{~s}$.

Одержано статтю: 3.10 .2019

Прийнято до друку: 25.10.2019 